\title{
To advise and scrutinize the government? Two types of political knowledge, political trust and unconventional participation
}

\author{
Piotr Michalski ${ }^{1}$ (1) - Marta Marchlewska ${ }^{1} \cdot$ Aleksandra Furman $^{2} \cdot$ Dagmara Szczepańska $^{1} \cdot$ Orestis Panayiotou $^{1}$. \\ Zuzanna Molenda ${ }^{1}$ P Paulina Górska²
}

Accepted: 22 November 2021

(c) The Author(s) 2021

\begin{abstract}
Well-functioning democracies depend on citizens' ability to make accurate political judgments and express them in the public sphere. Thus, in this research, we aim to better understand the role of political knowledge and political trust in shaping young Poles' willingness to engage in unconventional participation such as signing a petition, boycotting specific products, taking part in a peaceful demonstration, or engaging in social media activities. We distinguish between two types of political knowledge: knowledge about the rules of the game and current political knowledge, which provide a more insightful look into the complex nature of relationships between political knowledge, political trust, and unconventional participation. In two studies (Study 1, N=570 and Study 2; N=1048) we found that unconventional participation was positively predicted by political trust, and political knowledge about the rules of the game. We also found a significant interaction effect between political trust and current political knowledge, suggesting that those high in current political knowledge may be more willing to participate only when being distrustful towards the current political system. Implications and limitations of these findings are discussed.
\end{abstract}

Keywords Unconventional political participation · Political trust · Political knowledge $\cdot$ Young adults

\section{Introduction}

Democracy cannot thrive in the absence of citizen participation. As Dalton stated: "Without public involvement in the process, democracy loses both its legitimacy and its guiding force" (Dalton, 2008, p. 35). However, recent studies have delivered some disturbing results regarding young people's willingness to engage in politics. Specifically, it seems that they are disengaging from political life (Arvanitakis \& Marren, 2009; Henn \& Weinstein, 2006; Henn et al., 2002) and are dissatisfied with, as well as alienated from politics (Henn et al., 2005; Kimberlee, 2002; Wattenberg, 2002). The aforementioned trends are especially visible in young democracies where political culture is not deeply rooted in everyday life (Grasso, 2018; Kitanova, 2020). This 'gradual

Piotr Michalski

pmichalski@psych.pan.pl

1 Institute of Psychology, Polish Academy of Sciences, Jaracza 1, 00-001 Warsaw, Poland

2 Faculty of Psychology, University of Warsaw, Warsaw, Poland depoliticization' seems to threaten the future of liberal democracy because without participation, elected political elites do not have the necessary democratic legitimacy to represent the will of the people. Recent research showed that young people are becoming less prone to support democratic values (The Economist Intelligence Unit, 2020; Wuttke et al., 2020; Zilinsky, 2019). This is also the case among the citizens of Central and Eastern European countries who consistently show low levels of political trust (van der Meer, 2017). We could therefore wonder why young people avoid engaging in democratic processes. Is it because they do not trust democratic institutions or political actors? Or maybe because they lack the necessary political knowledge allowing them to engage in different forms of participation?

\section{Youth and Participation}

Involvement in formal political and electoral processes or structures (e.g., voting, standing as a candidate in political elections, being a member of a political party etc.) is usually the first thing which comes to mind when trying to define political participation. Indeed, many authors have 
considered this mode of conventional participation as a prerequisite of a well-functioning democracy (Fieldhouse et al., 2007; Norris, 2002; Verba et al., 1995; Wagner et al., 2012). Nonetheless, active citizenship is not limited exclusively to this type of engagement. During the time in between parliamentary and presidential elections citizens can express their needs or dissatisfaction in other ways (e.g., signing a petition or taking part in demonstrations) which, in ideal political circumstances, should be considered as guidance for the elected officials. Therefore, in order to fully understand why some people engage in political activities, we should focus on other modes of political participation, extending beyond formal forms of participation usually operationalized as voter turnout.

As previous studies have shown, young people tend to prefer unconventional modes of political participation which are more "cause oriented" (Pattie et al., 2004) and direct (e.g., support of referendums; Greaves et al., 2020). The definition of unconventional participation was introduced by Barnes and Kaase (1979). According to these authors, this type of engagement refers to any "non-institutionalized direct political action that does not aim to disrupt or threaten the stability of liberal democracies" (Barnes \& Kaase, 1979, p. 27). Unconventional participation can take many forms, such as signing a petition, boycotting specific products, taking part in a peaceful demonstration, or even engaging in social media activities (Ohme et al., 2018). What these and many other forms of unconventional participation have in common is that they are politically motivated, are carried out outside of the institutions and the state's initiatives and enable citizens to express their views on specific political decisions or policies (Ohme et al., 2018; van Deth, 2014).

Many studies conducted on Western societies have reported the youth's preference for unconventional forms of participation over conventional modes of involvement (Pickard \& Bessant, 2017), which could be a sign of a gradual process of reshaping modern politics (Dalton, 2008). This means that the young do not necessarily disengage from politics but rather that they prefer other forms of participation. One could ask what drives young people to engage particularly in unconventional participation. Two within-individual factors responsible for this mode of participation emerge from over 40 years of research on this subject - political knowledge and political trust. Although these predictors of unconventional participation were studied numerous times, the reason why they shape political engagement of modern youth is still widely discussed. Thus, studying the concomitants of the unconventional forms of political involvement may be the best way to fully understand why young people engage (vs. do not engage) in politics. It may also be helpful in predicting possible changes shaping the future of democratic systems.

\section{Political Knowledge and Participation}

Political knowledge is defined by Delli Carpini and Keeter (1996) as "the range of factual information about politics that is stored in long-term memory" (p. 10). Results of many studies have shown that more informed citizens are more likely to engage in various forms of political activities (e.g., Arnold, 2012; Delli Carpini \& Keeter, 1996; Hooghe \& Marien, 2013; Oscarsson, 2007). Political knowledge is often viewed as a personal resource which allows citizens to make accurate judgments about current political issues and aids them to translate this information into meaningful forms of participation (Delli Carpini $\&$ Keeter, 1996). When faced with a decision on which candidate to vote for, citizens often rely on specific information about the candidate's competence and views on political matters. However, when feeling discontent with the current government's decisions, citizens need to know what can be done to persuade the government to comply with their will.

In line with this logic, Johann (2012) argues that to better understand how political knowledge influences different types of political participation we should first distinguish between two types of political knowledge, namely - knowledge about the rules of the game and knowledge about political actors. Knowledge about the rules of the game consists of the information on how the political system works and how it is structured (Johann, 2012). Citizens unaware of the ways in which the political system functions may be unfamiliar with the possibilities to express their opinions on governmental decisions other than casting a vote in the next elections. Therefore, knowing the rules of the game should promote unconventional participation by equipping the citizens with the information about diverse ways of engaging in politics.

Knowledge about political actors consists of the information about important political figures. Not knowing these facts may hamper political judgments as citizens are not able to differentiate between political actors. Indeed, Johann's (2012) research demonstrated that knowledge about political actors positively predicted voting. What seems missing from Johann's (2012) definition of knowledge about political actors is that it should also contain factual information related to current political issues. Since this dimension serves participation by helping our political judgements to be more accurate (Delli Carpini \& Keeter, 1996), it should contain not only facts about who the most influential politicians are but also how they act and what decisions they make. This missing part in Johann's (2012) operationalization could have a significant impact on determining the influence of the knowledge about political actors on unconventional participation. 
Therefore, we argue that a more theoretically suitable name for this dimension of political knowledge is current political knowledge.

\section{Political Trust and Participation}

Moreover, as we mentioned above, political trust may also influence unconventional participation. Political trust "refers to citizens' assessments of the core institutions of the polity and entails a positive evaluation of the most relevant attributes that make each political institution trustworthy, such as credibility, fairness, competence, transparency in its policy-making, and openness to competing views" (Zmerli, 2014, p. 4887). It is based on the attitudes and values which develop in early life and are intergenerationally transmitted (Inglehart, 1997; Putnam, 2000). Political trust derives from interpersonal trust - one of the main components of the social capital (Putnam, 1993). Although in the early stages of life the two types of trust are assumed to be closely related, they tend to drift apart depending on one's knowledge and direct experiences with political institutions (Evans \& Whitefield, 1995; Hudson, 2006; Nye et al., 1997; Schoon \& Cheng, 2011). By direct experiences we do not necessarily mean interpersonal contacts with politicians or government officials, but observations of how their decisions and actions influence everyday life, such as food prices or unemployment (Popkin, 1991).

Research on the relationship between this construct and political participation showed mixed results. Although political trust influenced voter turnout positively (Dalton, 2004; Goul Andersen \& Hoff, 2001; Hooghe \& Quintelier, 2013; Norris, 2002; Zmerli \& Newton, 2008), its connection with unconventional participation is less clear. On one hand, some studies suggested that people who distrust political actors and institutions tend to engage more in political protest actions (Hooghe \& Marien, 2013; Hooghe \& Quintelier, 2013; Kaase, 1999; Norris, 1999; Rivat \& Stauer, 2012). On the other, previous research also revealed contradictory results, showing that specific forms of protest, such as issueoriented participation or product boycotts, were positively predicted by political trust (Dalton, 2004; Goul Andersen $\&$ Hoff, 2001). These discrepancies could derive from a difference in the character of these political actions' goals. According to van Deth's (2014) model, unconventional participation is focused on the general political sphere and not necessarily has to confront the government as a whole. Furthermore, if youth engagement is currently mainly issue-oriented (Norris, 2002), then actions could be taken to express their views on a specific policy rather than their general dissatisfaction with the elites. Paradoxically, political trust could enhance the probability of youth engagement because 'the trustworthy' government will adjust its actions according to the will of the people.

\section{Overview}

In accord with the abovementioned theories and studies, in the present paper we are attempting to understand what enhances young people's unconventional participation. Although numerous studies have tried to determine the significance of political knowledge and political trust, the way in which these two predictors interact to shape political unconventional engagement has not been considered yet. Furthermore, the distinction between two types of political knowledge introduced by Johann (2012) should grant a better understanding of the processes behind the political participation of youth. If current political knowledge and knowledge about the rules of the game are indeed qualitatively distinct, it is possible that their influence on the unconventional political engagement could differ depending on the level of political trust. This points us to the question about the type of political information citizens need to engage in politics. Is knowing the rules of democracy sufficient to act, even if we do not trust the government? Or maybe some specific information about the political actors or events in the political sphere pushes people to action only if they distrust the government and democratic institutions? By answering these questions we could construct more effective interventions and therefore give democracy active citizens which it needs in order to thrive.

Johann (2012) has observed that knowledge about the rules of the game enhances unconventional participation. This type of factual information contains "recipes" on how to act in order to get what we want from the political elites. That is, knowledge about the rules of the game provides the tools for an effective expression of dissatisfaction on specific political issues. Therefore, we hypothesised that:

\section{H1. Political knowledge about the rules of the game will be positively related to unconventional participation.}

The second type of knowledge which enhances political participation according to Johann (2012) is the knowledge about political actors. ${ }^{1}$ In his studies, he observed that knowledge about political actors influences the probability of becoming a voter. As Delli Carpini and Keeter (1996) stated, this type of information helps to identify what is in our best interest and to act accordingly. Although Johann (2012) believed that knowledge about political actors influences mainly voting and helping citizens to differentiate between political candidates, we believe this type of knowledge to be more general. Therefore, we expect knowledge

\footnotetext{
${ }^{1}$ We will refer to this dimension of political knowledge as current political knowledge in present paper
} 
about political actors to enhance other modes of participation as well, including unconventional participation. We assumed that:

\section{H2. Current political knowledge will be positively related to unconventional participation.}

Christensen (2018) also showed that direct democratic involvement, which can be perceived as a form of unconventional participation, is shaped by political distrust, political knowledge and their interaction. In the author's words, "this mutually reinforcing effect means that people who are knowledgeable and distrusting are much more likely to become involved, whereas the predicted probability of involvement is much lower when only one of the factors contributes to the outcome" (Christensen, 2018, p. 589). This result is in accord with the concept of "critical citizens" (Norris, 2002) which argues that political knowledge is a construct differentiating the vigilant citizens who scrutinize the actions of the political elites from the citizens who do not participate in politics at all. In other words, distrust toward the political institutions is not always a dangerous phenomenon for modern democracies as long as it is accompanied by high political knowledge - without it, people become cynical and apathetic towards the political processes, hence they retreat from engaging in politics. Therefore, we hypothesize that:

\section{H3. Current political knowledge and political trust will interact to enhance unconventional participation. Specifi- cally, current political knowledge will serve as a posi- tive predictor of unconventional participation, especially among those low in political trust.}

Summary of hypothesized relations between two types of political knowledge, political trust, and unconventional participation is presented in Table 1 .

We aim to validate our predictions in two studies conducted in a post-Communist country - Poland, which tends to score low on scales of democratization and participation (The Economist Intelligence Unit, 2020). We focused specifically on young people, because unconventional participation seems more appealing to them than taking part in formal democratic processes (Norris, 2002). In both studies, we aimed to include at least 400 participants, which gave us a power of .80 for detecting even small associations between variables (for $r=.14$; Cohen, 1988; $\mathrm{G}^{*}$ Power yields a target of 395 participants). Study 1 aims to determine whether political knowledge about the rules of the game and about political actors enhances unconventional participation. Furthermore, we wanted to investigate the conjoint influence of these focal predictors. The purpose of Study 2 is to confirm the observed relationships on a larger, representative sample

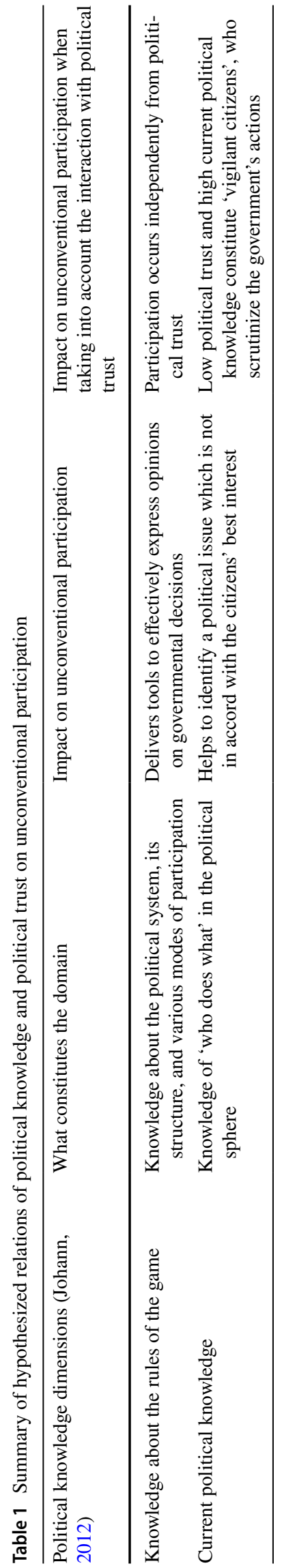


of young people. In this case, we also accounted for the effects of internal efficacy - a subjective evaluation of the respondents' own ability to influence politics, and of external efficacy - their subjective evaluation of the politicians' responsiveness to the citizens' needs (Almond \& Verba, 1965; Balch, 1974). Previous studies have shown that political participation is predicted by both internal (Krampen, 2000; Reichert, 2016) and external (de Moor, 2016) efficacy. Data for both studies, syntaxes and additional materials are available at: https://osf.io/5h8fr/?view_only=31b897ad20 074eecbcf57007fed7a80f

\section{Study 1}

\section{Method}

\section{Participants and Procedure}

Study 1 was conducted on a representative sample of young Poles via an online research panel in June 2019. The final sample consisted of 570 participants, 284 women and 286 men, aged between 18 and $25(M=22.14, S D=2.24)$. We have acquired an ethical approval of the Ethic Committe of Institute of Psychology, Polish Academy of Sciences for both presented studies. We measured two types of political knowledge and political trust as predictors, and political participation as the dependent variable. We also included measures of sex, education, political orientation and interpersonal trust. ${ }^{2}$

\section{Measures}

Current Political Knowledge was measured with five items referring to recent events in Polish politics and to current political actors, for example - who won the 2019 parliamentary elections in Poland, or who introduced a draft amendment to the Penal Code regarding 'the public propagation or approval of behaviours of pedophile nature'. Items were designed as multiple-choice questions in which the participants were provided with a set of possible answers, only one of them correct and one stating "I do not know". They were asked to choose one they believed was correct, $\alpha=.53$, $M=0.52, S D=0.24$. Higher mean score indicated higher current political knowledge. Full set of the items used in this study, together with the answers, can be found in the Supplement materials.

\footnotetext{
${ }^{2}$ Beside the variables reported here, Studies 1 and 2 also involved measures of individual differences variables included for the purposes of different projects employing the same predictors (please contact the corresponding author for details).
}

Political Knowledge about the Rules of the Game was measured with four items, for example - who has the legislative initiative regarding the national budget and what the rules on organising public gatherings are. Items were designed as multiple-choice questions in which the participants were provided with a set of possible answers, only one of them correct and one stating "I do not know". Participants were asked to choose one they believed was correct, $\alpha=.68$, $M=0.39, S D=0.34$. Higher mean score indicated higher political knowledge about the rules of the game. The full set of the items used in this study, together with the answers, can be found in the Supplement materials.

Political Trust was measured with seven items, used previously in the European Social Survey (2018), asking about the participants' trust in: the Polish Parliament, the Polish justice system, the police, politicians in general, political parties, the European Parliament and the United Nations. Participants responded on scales from 1 (low trust) to 10 (high trust) $\alpha=.90, M=5.18, S D=1.84$. Higher mean score indicated higher political trust.

Interpersonal Trust was measured with seven items (Różycka, 2012; see also Marchlewska et al., 2019), for example, "Most people can be trusted." or "In general, people are inherently good.". Participants responded on scales from 1 (definitely disagree) to 5 (definitely agree) $\alpha=.90$, $M=3.17, S D=0.77$. Higher mean score indicated higher interpersonal trust.

Political Orientation was measured with an item: "In political matters, people talk of 'the left' and 'the right'. How would you place your views on this scale, generally speaking?". They responded on scales from 1 (extremely left-wing/liberal) to 7 (extremely right-wing/conservative). Participants were also able to choose "I don't know/it's difficult to say" and "I refuse to answer", which were coded as missing data. Higher mean score indicated higher rightwing/conservative identification $(M=4.69, S D=1.6)$.

Political Participation was measured with nine items. Participants were asked how likely it was that they would take part in the listed activities within the following six months: "Speaking out about a political/social issue on social media (i.e., in the form of a post)", "Taking part in a demonstration/a political gathering"," Adding a frame related to political/social issues to their profile picture on Facebook", "Getting engaged in works for a group/an organisation representing specific socio-political or religious views", "Donating money for political/social causes", "Fundraising for political/social causes", "Disseminating informative materials about political/social issues", "Signing a petition", "Discussing political/social issues with family or friends." Participants responded on scales from 1 (extremely unlikely) to 5 (extremely likely) $\alpha=.92, M=2.52, S D=0.92$. Higher mean score indicated higher political participation. 
Table 2 Correlations between the continuous variables (Study 1)

\begin{tabular}{llllllll}
\hline Variable & 1 & 2 & 3 & 4 & 5 & 6 & 7 \\
\hline 1. Current political knowledge & - & & & & & \\
2. Knowledge about rules of the game & $.513^{* * *}$ & - & & & & & \\
3. Political trust & $-.121^{*}$ & $-.120^{*}$ & - & & & \\
4. Interpersonal trust & -.021 & .018 & $.347^{* *}$ & - & & \\
5. Political orientation & $-.093^{+}$ & $-.147^{* *}$ & $.298^{* *}$ & $.244^{* *}$ & - & & \\
6. Education & $.104^{*}$ & $.114^{*}$ & .034 & $.080^{+}$ & -.002 & - & \\
7. Unconventional political participation & .037 & $.08^{+}$ & $.290^{* *}$ & $.194^{* *}$ & .054 & $.079^{+}$ & - \\
\hline${ }^{* *} p<.001^{*} p<.05^{+} p<.06$ & & & & & & &
\end{tabular}

\section{Results}

\section{Zero-Order Correlations}

Political participation was positively correlated with political and interpersonal trust and with knowledge about the rules of the game. We did not find a significant relationship between political participation and current political knowledge or education. Both types of political knowledge were significantly positively correlated to each other and to education. We also found a negative relationship between the two types of political knowledge and political trust but not with interpersonal trust (Table 2).

\section{Regression Analysis}

Next, we examined the regression model with political participation as the dependent variable. In the first step, we introduced both types of political knowledge and political trust. ${ }^{3}$ As predicted, we found that knowledge about the rules of the game (but not current political knowledge) was significantly positively related to political participation. We also found a positive effect of political trust on political participation.

In the second step, we introduced two two-way interactions of both types of political knowledge and political trust. Again, we found significant positive effects of political knowledge about the rules of the game and political trust on unconventional political participation, but no significant effect of the current political knowledge. However, the interaction of current political knowledge and political trust was significant. Simple slope analysis indicated that current political knowledge predicted participation significantly and

\footnotetext{
${ }^{3}$ We have also performed a regression analysis with general political knowledge as a predictor (operationalized as mean from all knowledge questions). Results revealed that general knowledge significantly predicted participation $(B=0.13, p<0.01)$ while its interaction with political trust was not significant $(B=-0.07, p>0.05)$. See supplement materials for detailed results.
}

positively only among those who scored low ( $-1 \mathrm{SD})$ on political trust, $B=0.74, S E=0.24, p=.002$. We did not find a significant effect of current political knowledge on political participation among people with average $(\mathrm{M}), B=0.24$, $S E=0.15, p=.12$, or high (1 SD) political trust, $B=0.02$, $S E=0.18, p=.92$. Simple slope analysis also indicated that political trust predicted unconventional participation positively and significantly among those who scored low $(B=0.22, S E=0.03, p<.001)$, average $(B=0.13, S E=0.21$, $p<.001)$ and high $(B=0.09, S E=0.03, p<.01)$ in current political knowledge. The Johnson-Neyman test revealed that the relationship between political trust and participation was significant when centered current political knowledge was less than .38. When we adjusted for demographics, political orientation and interpersonal trust, the pattern of results for our focal predictors remained the same (Table 3 and Fig. 1).

\section{Discussion}

The results of Study 1 have shown that knowledge about the rules of the game was positively correlated with unconventional participation, which confirmed H1. However, we found no straightforward relationship between political participation and current knowledge, which in turn disproved H2. Nonetheless, we have observed an interaction between political trust and current knowledge. Not only does this effect prove $\mathrm{H} 3$, but it also provides an additional understanding of the conjoint influence of these predictors on unconventional types of participation. Specifically, we found that the effect of current political knowledge on unconventional participation was significant only among those who scored low in political trust. This would suggest that those possessing knowledge on current political issues may indeed be more willing to participate, but only when being distrustful towards the political institutions. The results obtained in Study 1 demonstrate that as far as political participation is concerned, the interaction between knowledge and political trust is valid not only within the Finnish context discussed by Christensen (2018). It equally applies to the so-called 'young democracies' like Poland, therefore allowing to 
Table 3 Summary of hierarchical analysis for unconventional political participation with confidence intervals (Study 1)

\begin{tabular}{|c|c|c|c|c|c|}
\hline Variable & $\mathrm{B}[95 \% \mathrm{CI}]$ & SE B & $\beta$ & $R^{2}$ & $\Delta R^{2}$ \\
\hline Step 1 & & & & .08 & $.08^{* * *}$ \\
\hline Constant & $2.58[2.49,2.66]$ & .04 & & & \\
\hline Current political knowledge & $0.06[-0.33,0.45]$ & .20 & .02 & & \\
\hline Knowledge about rules of the game & $0.37[0.09,0.65]$ & .14 & $.14^{*}$ & & \\
\hline Political trust & $0.13[0.09,0.18]$ & .02 & $.26^{* * * *}$ & & \\
\hline \multicolumn{6}{|l|}{ Step 2} \\
\hline Constant & $2.56[2.48,2.65]$ & .04 & & .09 & $.02^{*}$ \\
\hline Current political knowledge & $0.19[-0.21,0.58]$ & .20 & .05 & & \\
\hline Knowledge about rules of the game & $0.36[0.08,0.64]$ & .14 & $.13^{*}$ & & \\
\hline Political trust & $0.14[0.09,0.19]$ & .02 & $.27^{* * * *}$ & & \\
\hline Current political knowledge $\mathrm{X}$ political trust & $-0.03[-.052,-0.09]$ & .11 & $-.14^{* *}$ & & \\
\hline Knowledge about rules of the game $\mathrm{X}$ political trust & $0.07[-0.08,0.22]$ & .08 & .05 & & \\
\hline Step 3 & & & & .11 & .01 \\
\hline Constant & $2.37[2.08,2.66]$ & .15 & & & \\
\hline Current political knowledge & $0.14[-0.26,0.54]$ & .20 & .04 & & \\
\hline Knowledge about rules of the game & $0.32[0.04,0.60]$ & .14 & $.12^{*}$ & & \\
\hline Political trust & $0.13[0.08,0.18]$ & .03 & $.24^{* * *}$ & & \\
\hline Current political knowledge $X$ political trust & $0.27[-0.49,-0.05]$ & .11 & $-.13^{*}$ & & \\
\hline Knowledge about rules of the game $\mathrm{X}$ political trust & $0.07[-0.08,0.21]$ & .08 & .05 & & \\
\hline Interpersonal trust & $0.12[0.00,0.24]$ & .06 & $.10^{*}$ & & \\
\hline Political orientation & $0.01[-0.07,0.04]$ & .03 & -.02 & & \\
\hline Education & $0.10[-0.04,0.24]$ & .07 & .06 & & \\
\hline Gender $(1=$ female; $0=$ male $)$ & $0.02[-0.15,0.19]$ & .09 & .01 & & \\
\hline
\end{tabular}

predict unconventional modes of participation in such contexts more accurately. Finally, it extends beyond the citizens' initiatives studied by Christensen (2018), as our Study also included other forms of unconventional participation, such as signing a petition, taking part in protests or social media activity.

\section{Study 2}

\section{Method}

\section{Participants and Procedure}

Study 2 was conducted on a representative sample of young Poles via an online research panel in December 2019. The final sample consisted of 1048 participants, 547 women and 501 men, aged between 18 and $25(M=22.35, S D=2.16)$. As in Study 1, we measured two types of political knowledge and political trust as predictors, and political participation as the dependent variable. We also measured sex, education, political orientation, interpersonal trust, internal and external efficacy. ${ }^{4}$

${ }^{4}$ This dataset was also used by Cislak et al. (2021).

\section{Measures}

Current Political Knowledge was measured with two items, used in Study 1, asking about such issues as: who won the 2019 parliamentary elections in Poland and what the tax relief for young people included. Participants were asked to choose the answer they believed was correct, $r=.60$, $M=0.63, S D=0.40$. Higher mean score indicated higher current political knowledge.

Knowledge about the Rules of the Game was measured with three items, used in Study 1, referring to the definition of pluralism, the rule of the separation of powers and political gatherings. Participants were asked to choose the answer they believed was correct, $\alpha=.69, M=0.40, S D=0.38$. Higher mean score indicated higher knowledge about rules of the game.

Political Trust was measured with two items regarding participants' trust in: political parties and politicians in general. Participants responded on scales from 1 to $5, r=.91$, $M=2.16, S D=1.03$. Higher mean score indicated higher political trust.

Interpersonal Trust was measured in the same way as in Study $1, \alpha=.91, M=3.07, S D=0.78$. Higher mean score indicated higher interpersonal trust. 
Fig. 1 Political trust as a moderator of the effect of current political knowledge on political participation (Study 1)

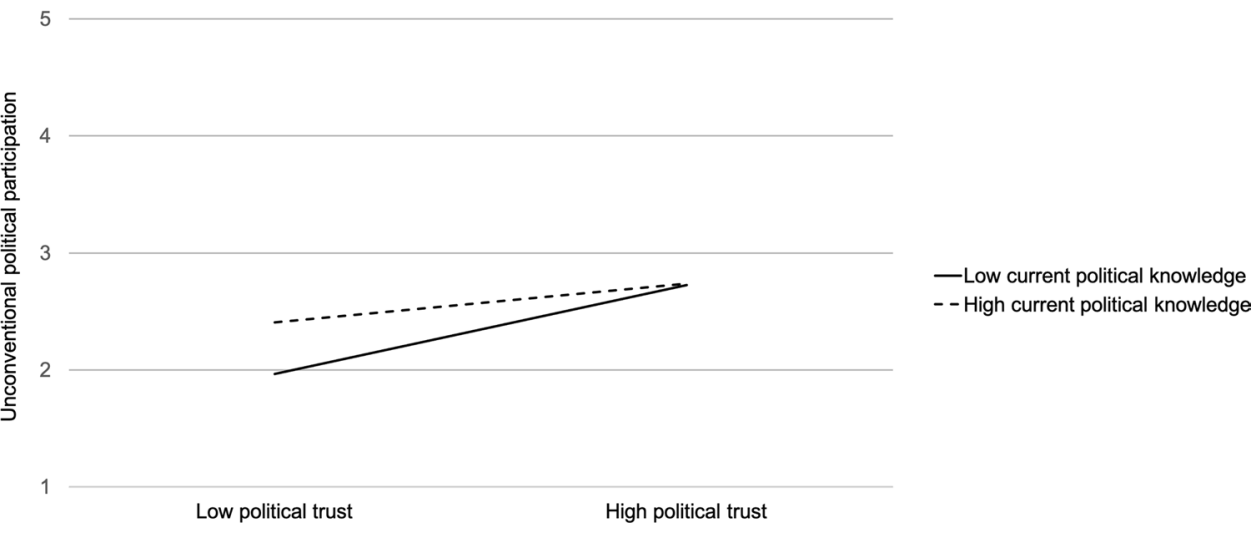

Political Orientation was measured with the same item as in Study $1, M=3.93, S D=1.40$. However, we have removed the answer options which generated missing data in Study 1. Higher mean score indicated higher right-wing/ conservative identification.

Internal Efficacy was measured with two items: "I have an impact on what is happening in politics" and "I think my vote in elections (parliamentary and presidential) and referendums etc. matters". Respondents answered on a scale from 1 (I definitely disagree) to 5 (I definitely agree), $r=.67$, $M=2.89, S D=0.91$. Higher mean score indicated higher internal efficacy.

External Efficacy was measured with two items: "Public officials care for what I and people like me think" and "Politicians react to citizens' demands". Respondents answered on a scale from 1 (I definitely disagree) to 5 (I definitely agree), $r=.83, M=2.46, S D=0.94$. Higher mean score indicated higher external efficacy.

Political Participation was measured with nine items, in the same way as in Study $1, \alpha=.92, M=2.36$, $S D=0.95$.

\section{Results}

\section{Zero-Order Correlations}

Results were very similar to the ones derived from Study 1. Political participation was positively correlated with political and interpersonal trust and with knowledge about the rules of the game. Again, we did not find a significant relationship between political participation and current political knowledge or education. Both types of political knowledge were significantly positively related to each other. As in Study 1, we found negative relationships between the two types of political knowledge and political (but not interpersonal) trust. We also found positive relationships between two types of trust and internal and external efficacy. Furthermore, both types of political knowledge were negatively correlated with external efficacy and political trust. Finally, we found positive relationships between education and both types of political knowledge (Table 4).

\section{Regression Analysis}

We then examined the regression model with political participation as the dependent variable. In the first step, we introduced two types of political knowledge and political trust. ${ }^{5}$ The outcome was significant. As in Study 1, we found that political knowledge about the rules of the game (but not current political knowledge) was significantly positively related to unconventional participation. We also found a positive effect of political trust on unconventional participation.

In the second step, we introduced two two-way interactions of both types of political knowledge and political trust. We found a significant positive effect of political knowledge about the rules of the game and of political trust on unconventional participation. The interaction of current political knowledge and political trust was also significant. Simple slope analysis indicated that current political knowledge predicted political participation significantly and positively only among those who scored low $(B=0.71$, $S E=0.11, p<.001)$ or average $(B=0.38, S E=0.07, p<.001)$ on political trust. We did not find a significant effect of current political knowledge on unconventional participation among people high in political trust, $B=0.05, S E=0.08$, $p=.54$. Simple slope analysis also indicated that political trust predicted unconventional participation significantly

\footnotetext{
$\overline{5}$ We have also performed a regression analysis with general political knowledge as a predictor (operationalized as mean from all knowledge questions). Results revealed that general knowledge was a significant predictor of participation $(B=0.10, p<0.001)$. Its interaction with political trust was also significant $(B=-0.11, p<0.001)$. See supplement materials for detailed results.
} 
Table 4 Correlations between the continuous variables (Study 2)

\begin{tabular}{|c|c|c|c|c|c|c|c|c|c|}
\hline Variable & 1 & 2 & 3 & 4 & 5 & 6 & 7 & 8 & 9 \\
\hline 1. Current political knowledge & - & & & & & & & & \\
\hline 2. Knowledge about rules of the game & $.516^{* *}$ & - & & & & & & & \\
\hline 3. Political trust & $-.262^{* *}$ & $-.291^{* *}$ & - & & & & & & \\
\hline 4. Interpersonal trust & -.004 & -.021 & $.248^{* *}$ & - & & & & & \\
\hline 5. Internal efficacy & .048 & .042 & $.415^{* *}$ & $.313^{* *}$ & - & & & & \\
\hline 6. External efficacy & $-.228^{* *}$ & $-.284^{* *}$ & $.647^{* *}$ & $.278^{* *}$ & $.491^{* *}$ & - & & & \\
\hline 7. Political left/right orientation & -.042 & $-.067^{*}$ & $.300^{* * *}$ & $.184^{* *}$ & $.219^{* *}$ & $.330^{* *}$ & - & & \\
\hline 8. Education & $.224^{* *}$ & $.236^{* *}$ & $-.091^{*}$ & .015 & $-.060^{+}$ & $-.115^{* *}$ & .029 & - & \\
\hline 9. Unconventional political participation & .021 & .045 & $.35^{* *}$ & $.218^{* *}$ & $.379^{* *}$ & $.265^{* *}$ & $.094^{*}$ & .009 & - \\
\hline
\end{tabular}

${ }^{* *} p<.001{ }^{*} p<.05^{+} p<.06$

and positively among the respondents who scored low $(B=0.55, S E=0.48, p<.001)$, average $(B=0.39, S E=0.28$, $p<.001)$ and high on current political knowledge $(B=0.22$, $S E=0.38, p<.001)$. The Johnson-Neyman test revealed that the relationship between political trust and participation was significant on all levels of current political knowledge. Importantly, when we adjusted for sex, education, political orientation, interpersonal trust, internal and external efficacy, the pattern of results for our focal predictors remained the same (Table 5 and Fig. 2).

Table 5 Summary of hierarchical analysis for unconventional political participation with confidence intervals (Study 2)

\begin{tabular}{|c|c|c|c|c|c|}
\hline Variable & $\mathrm{B}[95 \% \mathrm{CI}]$ & SE B & $\beta$ & $R^{2}$ & $\Delta R^{2}$ \\
\hline Step 1 & & & & .15 & $.15^{* * *}$ \\
\hline Constant & $2.33[2.28,2.39]$ & .03 & & & \\
\hline Current political knowledge & $0.14[-0.02,0.29]$ & .08 & .06 & & \\
\hline Knowledge about rules of the game & $0.33[0.16,0.50]$ & .09 & $.13^{* * *}$ & & \\
\hline Political trust & $0.37[0.32,0.43]$ & .03 & $.40^{* * * *}$ & & \\
\hline Step 2 & & & & .17 & $.02^{* * *}$ \\
\hline Constant & $2.30[2.25,2.36]$ & .03 & & & \\
\hline Current political knowledge & $0.20[0.04,0.35]$ & .08 & $.08^{*}$ & & \\
\hline Knowledge about rules of the game & $0.28[0.12,0.45]$ & .09 & $.11^{* *}$ & & \\
\hline Political trust & $0.36[0.31,0.42]$ & .03 & $.39^{* * * *}$ & & \\
\hline Current political knowledge $\mathrm{X}$ political trust & $-0.30[-0.45,-0.15]$ & .08 & $-.13^{* * *}$ & & \\
\hline Knowledge about rules of the game $\mathrm{X}$ political trust & $0.01[-0.18,0.16]$ & .09 & -.00 & & \\
\hline Step 3 & & & & .23 & $.07^{* * *}$ \\
\hline Constant & $2.34[2.13,2.54]$ & .10 & & & \\
\hline Current political knowledge & $0.11[-0.04,0.27]$ & .08 & .05 & & \\
\hline Knowledge about rules of the game & $0.20[0.04,0.37]$ & .08 & $.08^{*}$ & & \\
\hline Political trust & $0.25[0.18,0.32]$ & .04 & $.27^{* * * *}$ & & \\
\hline Current political knowledge $\mathrm{X}$ political trust & $-0.27[-0.41,-0.13]$ & .07 & $-.12^{* * *}$ & & \\
\hline Knowledge about rules of the game $\mathrm{X}$ political trust & $-0.04[-0.21,0.12]$ & .08 & -.02 & & \\
\hline Interpersonal trust & $0.10[0.03,0.17]$ & .04 & $.08^{* *}$ & & \\
\hline Internal efficacy & $0.25[0.19,0.32]$ & .04 & $.25^{* * * *}$ & & \\
\hline External efficacy & $0.00[-0.08,0.08]$ & .04 & .00 & & \\
\hline Political orientation & $-0.05[-0.09,-0.01]$ & .02 & $-.07^{*}$ & & \\
\hline Education & $0.02[-0.07,0.11]$ & .05 & .01 & & \\
\hline Gender $(1=$ female $; 0=$ male $)$ & $-0.14[-0.24,-0.03]$ & .05 & $-.07^{* *}$ & & \\
\hline
\end{tabular}

${ }^{*} p<.05 .{ }^{* *} p<.01 .{ }^{* * *} p<.001$ 
Fig. 2 Political trust as a moderator of the effect of current political knowledge on political participation (Study 2)
5

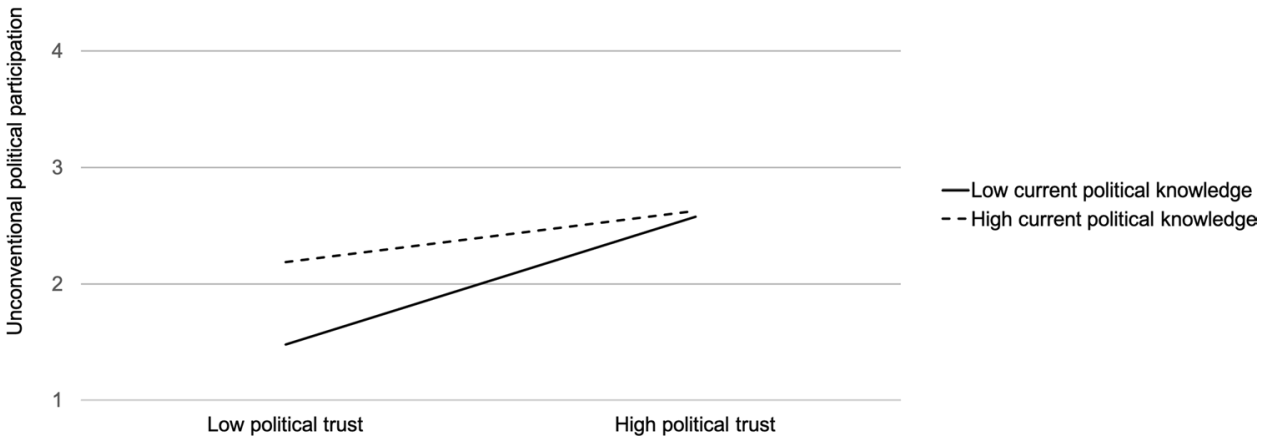

\section{Discussion}

Study 2 corroborated the results of Study 1 . Knowledge about rules of the game positively predicted unconventional participation, which confirmed H1. Once again did not find a straightforward significant relationship between current political knowledge and unconventional participation, hence $\mathrm{H} 2$ could not be confirmed. However, as in Study 1, the results indicated an interaction between current political knowledge and political trust. The pattern of conjoint effect of focal predictors on unconventional participation was similar to the one discovered in Study 1. Once again, we found that current political knowledge predicted participation significantly but only for those who scored low or average on political trust. Including internal and external efficacy as additional control variables did not change the main results in regard to neither political trust, political knowledge nor participation. Internal efficacy proved to be an independent predictor of unconventional participation. It also showed no significant relationship with either of the two dimensions of political knowledge, suggesting that these two variables are not connected. As for external efficacy, it was positively correlated with unconventional participation. However, its influence was no longer significant after including other variables into the model. This was due to the strong correlation between external efficacy and political trust, which is nothing new (e.g., Craig et al., 1990), but in the end political trust was a stronger predictor of unconventional participation.

\section{General Discussion}

Political knowledge enhances various forms of political engagement (Delli Carpini \& Keeter, 1996; Milner, 2002, 2008) and therefore some authors argue that it is not an unidimensional phenomenon (Iyengar, 1990; Johann, 2012). Following the work of Johann (2012) we have conducted two studies which include two types of political knowledge: knowledge about the rules of the game and current political knowledge. Our results indicate that distinguishing between these two dimensions of knowledge gives a better understanding of why young Poles engage (vs. do not engage) in unconventional participation.

Both of our studies show that political knowledge about the rules of the game is positively related to unconventional participation. Therefore, knowing the principles of democracy can probably make young people eager to engage in political actions. It seems that citizens with little knowledge about the democratic system could be more reluctant to become involved in a "game" which they do not understand. However, the results of Study 2 indicate that political knowledge about the rules of the game does not go hand in hand with the citizens' beliefs about their competence to effectively influence politics via unconventional participation (as no significant relationship between internal efficacy and political knowledge was found; see Table 3). Therefore, we argue that political knowledge about the rules of the game enhances unconventional participation not because it supports the beliefs about the efficiency of these actions, but because being aware of multiple ways of influencing the political sphere makes other opportunities for action more visible. Therefore, our studies have shown that engaging in unconventional participation is not a matter of pure disaffection with more formal modes of participation but rather an effect of being aware of different possibilities for expressing political views, other than voting.

Current political knowledge consists of facts about important figures in the political sphere and of information on what they are doing. Possessing this information was previously argued to have enhanced political participation, as it makes our political decisions easier (Lau \& Redlawsk, 2001). However, both of our studies have shown that this dimension of political knowledge was related to unconventional political participation only among those people who scored low or average (vs. high) on the scale of political trust. In other words, current political knowledge is not directly related to unconventional participation, but it enhances this mode of political participation 
when political trust is low or average. High current political knowledge and low political trust characterize „vigilant citizens" who scrutinize the government's actions and therefore strengthen democracy (Mishler \& Rose, 1997; Norris, 2011). These people do not rely fully on the officials' intention or ability to act in favor of the citizens' interests. Therefore, they monitor the public sphere and engage in actions which could prevent the political institutions from making bad decisions. However, if citizens possess high levels of current political knowledge and trust the government at the same time, they probably believe that the decision-makers will eventually do what is "right". Therefore, this configuration of political trust and current political knowledge undermine citizens' engagement in politics. Future studies should however determine whether this also applies to other types of political engagement besides unconventional participation. Numerous research have shown that political trust influences various modes of participation (e.g., Dalton, 2004; Hooghe \& Quintelier, 2013; Rivat \& Stauer, 2012), but the conjoint effect of political trust and both dimensions of political knowledge still needs further studies. We believe that a high level of knowledge about the rules of the game could predict engagement in various modes of political actions but it could also prevent nonnormative participation, as knowing how and when to act offers many possibilities to express political views other than e.g., violent protests.

Finally, there are also some limitations to our studies that should be pointed out. First, the cross-sectional nature of the studies does not allow to test for the directionality of the effects. We have decided to follow the guidelines by Grosz et al. (2020) to report and argue our causality assumptions because we believe that the debate about the links between political trust, political knowledge and participation should emphasize the direction of these relationships. We have assumed that political knowledge and political trust enhance unconventional participation but this direction of influence is debatable. Some researchers argue that engaging in political participation enhances political knowledge (Tolbert et al., 2003) while everyday life experiences with politics influence citizens' political trust (Popkin, 1991; Schoon \& Cheng, 2011). We have decided to make our assumptions about the causality based mainly on two reasons. One being the young age of the respondents. It is debatable whether our respondents did not have previous experiences in political participation as we did not control for this in our studies. However, we believe that they had less opportunities to engage in political activities than older Poles. Secondly, we have operationalized unconventional participation by asking about the intentions to engage in this type of activity. Although this does not disprove the argument about the influence of participation on political knowledge in general, we had no reasons to believe that the intention to act in this particular way influenced political trust and political knowledge. Still, future research would do well to test our assumptions with the use of a longitudinal and experimental research design.

Furthermore, there are also some limits to the generalisation of our results. In our studies we focused on youth participation, so our results should be treated carefully when thinking about wider populations, including other age cohorts. Young people are a specific group, as they are only now starting their political participation. Lack of experience may influence their political knowledge negatively (Bowyer et al., 2017; McAllister, 1998) and it may also be related to political trust, however, the results here often show more complicated effects. Some studies show that political trust declines with age (Citrin \& Stoker, 2018), however, as others indicate, it might also increase as political experience accumulates, under the condition that this experience is mostly positive (Schoon \& Cheng, 2011). Young people are also more open to the change, both in terms of the politicians and the parties that rule the country (Seagull, 1971), as well as in the modes of political actions (Alteri et al., 2017; Harris et al., 2010; Kovacheva, 2005).

What is more, our studies were conducted in Poland, where democracy is relatively young. Our participants are actually the first generation that was raised in a fully independent, democratic country. As we know that both political trust and knowledge are shaped during childhood, with family knowledge and trust playing a crucial part (Jennings et al., 2009; McIntosh et al., 2007), it might have an immense influence on Polish youth's democratic knowledge and attitudes, compared to their peers in countries with longer democratic traditions. Parents may not give the young the knowledge they do not have themselves, and school, as studies show, does not fill this gap (Furman et al., in press). Moreover, the previous political system in Poland - the people's democracy, left its imprints on the society and contributed to the low social and political trust (Hooghe et al., 2009; van der Meer, 2017). All in all, we may believe that the Polish young are a distinct group, and the results from our studies should be generalised with caution. Another potentially fertile ground for future studies would also be to replicate these results in other countries and cultures, especially beyond WEIRD contexts (Henrich et al., 2010).

Finally, we want to address limitations related to the method of data acquisition. Online survey conducted on a research panel could influence the results, especially when it comes to political knowledge questions. For example, we do not know whether the respondents used some help from other sources, such as search engines or other people, to answer these questions. Moreover, participants received symbolic gratification for filling out online questionnaires. Although we do not know whether 
this significantly influenced the political knowledge test results, previous studies have shown that motivation to answer these types of questions correctly has an impact on the final test's result (Prior \& Lupia, 2008). Finally, we did not control the level of focus or exhaustion of the respondents during the study. Although the company responsible for the gathering of the data introduced two attention checks to the questionnaire, we cannot be certain that other variables related to the physical state of the participants had an impact on the final results of the political knowledge test.

All the limitations considered, we believe that our studies shed a new light on the relationships between political knowledge and political trust, and they contribute to a better understanding of the antecedents of youth political participation.

\section{Conclusions}

The results of our studies have various implications for theory and practice in regard to political participation of youth. In fact, the two types of political knowledge distinguished by Johann (2012) predicted political engagement differently, which is an argument against treating political knowledge as a unidimensional phenomenon. While knowledge about the rules of the game predicted unconventional political participation in line with Johann's (2012) assumptions, current political knowledge enhanced unconventional participation only among people who distrust the government. These observations also have practical implications. Namely, in order for young people to be active in the political sphere they need to be provided with information on how the democratic system works and what they can do to effectively express their interests. We believe that this would be best achieved by introducing this type of knowledge to schools' curriculum. Enhancing current political knowledge seems to be more difficult as this kind of political knowledge quickly becomes outdated. Therefore, it seems that in order for young people to become 'vigilant citizens' (Norris, 2002) they need to develop internal motivation to monitor the political sphere.

Funding This work was supported by Polish Ministry of Science and Higher Education Grant (DIALOG Grant No. 0013/2019; financing period: 2019-2021) and Norface Democratic Governance in a Turbulent Age Research Programme (the project Threat, identity, and dissent: Understanding and addressing political polarization in European democracies is financially supported by the NORFACE Joint Research Programme on Democratic Governance in a Turbulent Age and co-funded by National Science Centre, Poland and the European Commission through Horizon 2020 under grant agreement No 822166).
Data Availability The datasets generated during and/or analyzed during the current study, syntaxes and additional materials are available in the Open Science Framework repository, https://osf.io/5h8fr/?view_only= 18cebbd2039f4d569e3e2d0c27523736

\section{Declarations}

Conflict of Interest We have no known conflict of interests to disclose.

Ethics Approval This study was performed in line with the principles of the Declaration of Helsinki. Approval was granted by the Ethics Committee of Institute of Psychology, Polish Academy of Sciences (18/XI/2019).

Informed Consent Informed consent was obtained from all individual participants included in the study.

Open Access This article is licensed under a Creative Commons Attribution 4.0 International License, which permits use, sharing, adaptation, distribution and reproduction in any medium or format, as long as you give appropriate credit to the original author(s) and the source, provide a link to the Creative Commons licence, and indicate if changes were made. The images or other third party material in this article are included in the article's Creative Commons licence, unless indicated otherwise in a credit line to the material. If material is not included in the article's Creative Commons licence and your intended use is not permitted by statutory regulation or exceeds the permitted use, you will need to obtain permission directly from the copyright holder. To view a copy of this licence, visit http://creativecommons.org/licenses/by/4.0/.

\section{References}

Almond, G. A., \& Verba, S. (1965). The civic culture: Political attitudes and democracy in five nations. Little, Brown and Company.

Alteri, L., Leccardi, C., \& Raffini, L. (2017). Youth and the reinvention of politics. New forms of participation in the age of individualization and presentification. Partecipazione e conflitto, 9(3), 717-747. https://doi.org/10.1285/i20356609v9i3p717

Arnold, J. R. (2012). The electoral consequences of voter ignorance. Electoral Studies, 31(4), 796-815. https://doi.org/10.1016/j.elect stud.2012.06.003

Arvanitakis, A., \& Marren, S. (2009). Putting the politics back into politics: Young people and democracy in Australia: Discussion paper. Foundation for Young Australians. https://researchdirect.westernsyd ney.edu.au/islandora/object/uws:32859/. Accessed 02/04/2021

Balch, G. I. (1974). Multiple indicators in survey research: The concept "sense of political efficacy". Political Methodology, 1(2), 1-43 http://www.jstor.org/stable/25791375

Barnes, S., \& Kaase, M. (Eds.). (1979). Political action: Mass participation in five Western democracies. Sage.

Bowyer, B. T., Kahne, J. E., \& Middaugh, E. (2017). Youth comprehension of political messages in YouTube videos. New Media \& Society, 19(4), 522-541. https://doi.org/10.1177/14614 44815611593

Christensen, H. (2018). Knowing and distrusting: How political trust and knowledge shape direct-democratic participation. European Societies, 20(4), 572-594. https://doi.org/10.1080/14616696. 2017.1402124

Citrin, J., \& Stoker, L. (2018). Political trust in a cynical age. Annual Review of Political Science, 21, 49-70. https://doi.org/10.1146/ annurev-polisci-050316-092550 
Cislak, A., Marchlewska, M., Wojcik, A. D., Śliwiński, K., Molenda, Z., Szczepańska, D., \& Cichocka, A. (2021). National narcissism and support for voluntary vaccination policy: The mediating role of vaccination conspiracy beliefs. Group Processes \& Intergroup Relations, 24(5), 701-719. https://doi.org/10.1177/1368430220 959451

Cohen, J. (1988). Statistical power analysis for the behavioral sciences (2nd ed.). Erlbaum.

Craig, S. C., Niemi, R. C., \& Silver, G. E. (1990). Political efficacy and trust: A report on the NES pilot study items. Political Behavior, 12(3), 289-314.

Dalton, R. J. (2004). Democratic challenges. Democratic choices: The erosion of political support in advanced industrial democracies. Oxford University Press. https://doi.org/10.1093/acprof:oso/ 9780199268436.001.0001

Dalton, R. (2008). Citizen politics: Public opinion and political parties in advanced industrial democracies. CQ Press.

de Moor, J. (2016). External efficacy and political participation revisited: The role of perceived output structures for state- and nonstate-oriented action forms. Parliamentary Affairs, 69(3), 642662. https://doi.org/10.1093/pa/gsv055

Delli Carpini, M. X., \& Keeter, S. (1996). What Americans know about politics and why it matters. Yale University Press.

European Social Survey. (2018). ESS-5 2010 Documentation Report. Edition 4.2. Bergen, European Social Survey Data Archive, NSD - Norwegian Centre for Research Data for ESS ERIC. 10.21338/NSD-ESS5-2010.

Evans, G., \& Whitefield, S. (1995). The politics and economics of democratic commitment: Support for democracy in transition societies. British Journal of Political Science, 25(4), 485-514. https://doi.org/10.1017/S0007123400007328

Fieldhouse, E., Trammer, M., \& Russel, A. (2007). Something about young people or something about elections? Electoral participation of young people in Europe: Evidence from a multilevel analysis of the European social survey. European Journal of Political Research, 46(6), 797-822. https://doi.org/10.1111/j. 1475-6765.2007.00713.x

Furman, A., Szczepańska, D., \& Maison, D. (in press). The role of family, peers and school in political socialisation - Quantitative and qualitative study of polish young adults' experiences. Citizenship Teaching \& Learning.

Goul Andersen, J., \& Hoff, J. (2001). Democracy and citizenship in Scandinavia. Palgrave Macmillan. https://doi.org/10.1057/ 9780230507968

Grasso, M. (2018). Young people's political participation in Europe in times of crisis. In S. Pickard \& J. Bessant (Eds.), Young people re-generating politics in times of crises (pp. 179-196). Palgrave Macmillan. https://doi.org/10.1007/978-3-319-58250$4 \_10$

Greaves, L., Oldfield, L., \& Milne, B. (2020). Let the people decide? Support for referenda since the New Zealand flag change referendums. Kōtuitui: New Zealand Journal of Social Sciences Online. Advance online publication. https://doi.org/10.1080/1177083X. 2020.1786413

Grosz, M. P., Rohrer, J. M., \& Thoemmes, F. (2020). The taboo against explicit causal inference in nonexperimental psychology. Perspectives on Psychological Science, 15(5), 1243-1255. https://doi.org/ $10.1177 / 1745691620921521$

Harris, A., Wyn, J., \& Younes, S. (2010). Beyond apathetic or activist youth: 'Ordinary' young people and contemporary forms of participation. Young, 18(1), 9-32. https://doi.org/10.1177/11033 0880901800103

Henn, M., Weinstein, M., \& Forrest, S. (2005). Uninterested youth? Young people's attitudes towards party politics in Britain. Political Studies, 53(3), 556-578. https://doi.org/10.1111/j.1467-9248. 2005.00544.x
Henn, M., \& Weinstein, M. (2006). Young people and political (in) activism: Why don't young people vote? Policy \& Politics, 34(3), 517-534. https://doi.org/10.1332/030557306777695316

Henn, M., Weinstein, M., \& Wring, D. (2002). A generation apart? Youth and political participation in Britain. The British Journal of Politics and International Relations, 4(2), 167-192. https://doi. org/10.1111/1467-856X.t01-1-00001

Henrich, J., Heine, S., \& Norenzayan, A. (2010). The weirdest people in the world? Behavioral and Brain Sciences, 33(2-3), 61-83. https://doi.org/10.1017/S0140525X0999152X

Hooghe, M., Reeskens, T., Stolle, D., \& Trappers, A. (2009). Ethnic diversity and generalized trust in Europe: A cross-national multilevel study. Comparative Political Studies, 42(2), 198-223. https://doi.org/10.1177/0010414008325286

Hooghe, M., \& Marien, S. (2013). A comparative analysis of the relation between political trust and forms of political participation in Europe. European Societies, 15(1), 131-152. https://doi.org/10. $1080 / 14616696.2012 .692807$

Hooghe, M., \& Quintelier, E. (2013). Political participation in Europe. In S. I. Keil \& O. W. Gabriel (Eds.), Society and democracy in Europe (pp. 220-243). Routledge.

Hudson, J. (2006). Institutional trust and subjective well-being across the EU. Kyklos, 59(1), 43-62. https://doi.org/10.1111/j. 1467-6435.2006.00319.x

Iyengar, S. (1990). Shortcuts to political knowledge: The role of selective attention and accessibility. In J. A. Ferejohn \& J. H. Kuklinski (Eds.), Information and democratic processes (pp. 160-185). University of Illinois Press.

Inglehart, R. (1997). Modernization and postmodernization: Cultural, economic, and political change in 43 societies. Princeton University Press.

Jennings, M. K., Stoker, L., \& Bowers, J. (2009). Politics across generations: Family transmission reexamined. The Journal of Politics, 71(3), 782-799. https://doi.org/10.1017/S002238160 9090719

Johann, D. (2012). Specific political knowledge and citizens' participation: Evidence from Germany. Acta Politica, 47, 42-66. https://doi.org/10.1057/ap.2011.20

Kaase, M. (1999). Interpersonal trust, political trust, and non-institutionalized political participation in Western Europe. West European Politics, 22(3), 1-21. https://doi.org/10.1080/01402 389908425313

Kimberlee, R. (2002). Why don't young people vote at general elections? Journal of Youth Studies, 5(1), 85-98. https://doi.org/10. 1080/13676260120111788

Kitanova, M. (2020). Youth political participation in the EU: Evidence from a cross-national analysis. Journal of Youth Studies, 23(7), 819-836. https://doi.org/10.1080/13676261. 2019.1636951

Kovacheva, S. (2005). Will youth rejuvenate the patterns of political participation. In J. Fobrig (Ed.), Revisiting youth political participation. Challenges for research and democratic practice in Europe (pp. 19-28). Council of Europe Publishing.

Krampen, G. (2000). Transition of adolescent political action orientations to voting behavior in early adulthood in view of a socialcognitive action theory model of personality. Political Psychology, 21(2), 277-299. https://doi.org/10.1111/0162-895X.00188

Lau, R. R., \& Redlawsk, D. P. (2001). Advantages and disadvantages of cognitive heuristics in political decision making. American Journal of Political Science, 45(4), 951-971. https://doi.org/10. 2307/2669334

Marchlewska, M., Castellanos, K. A., Lewczuk, K., Kofta, M., \& Cichocka, A. (2019). My way or the highway: High narcissism and low self-esteem predict decreased support for democracy. The British Journal of Social Psychology, 58(3), 591-608. https://doi. org/10.1111/bjso. 12290 
McIntosh, H., Hart, D., \& Youniss, J. (2007). The influence of family political discussion on youth civic development: Which parent qualities matter? PS. Political Science and Politics, 40(3), 495-499. https://doi.org/10.1017/S1049096507070758

McAllister, I. (1998). Civic education and political knowledge in Australia. Australian Journal of Political Science, 33(1), 7-23. https:// doi.org/10.1080/10361149850697

Milner, H. (2002). Civic literacy: How informed citizens make democracy work. University Press of New England.

Milner, H. (2008). The informed political participation of young Canadians and Americans. CIRCLE: The Center for Information \& Research on Civic Learning \& Engagement. https://circle.tufts. edu/sites/default/files/2019-12/WP60_InformedPoliticalPar ticipation YoungCanadiansandAmericans_2008.pdf. Accessed $10 / 04 / 2021$

Mishler, W., \& Rose, R. (1997). Trust, distrust and skepticism: Popular evaluations of civil and political institutions in post-communist societies. The Journal of Politics, 59(2), 418-451. https://doi.org/ 10.1017/S0022381600053512

Norris, P. (Ed.). (1999). Critical citizens. Global support for democratic governance. Oxford University Press. https://doi.org/10. 1093/0198295685.001.0001.

Norris, P. (2002). Democratic Phoenix: Reinventing political activism. Cambridge University Press. https://doi.org/10.1017/CBO97 80511610073

Norris, P. (2011). Democratic deficit: Critical citizens revisited. Cambridge University Press. https://doi.org/10.1017/CBO9780511 973383

Nye, J. S., Zelikow, P. D., \& King, D. C. (Eds.). (1997). Why people don't trust government. Harvard University Press.

Ohme, J., de Vreese, C., \& Albæk, E. (2018). From theory to practice: How to apply van Deth's conceptual map in empirical political participation research. Acta Politica, 53, 367-390. https://doi.org/ 10.1057/s41269-017-0056-y

Oscarsson, H. (2007). A matter of fact? Knowledge effects on the vote in Swedish general elections, 1985-2002. Scandinavian Political Studies, 30(3), 301-322. https://doi.org/10.1111/j.1467-9477. 2007.00182.x

Pattie, C., Seyd, P., \& Whiteley, P. (2004). Citizenship in Britain: Values, participation and democracy. Cambridge University Press. https://doi.org/10.1017/CBO9780511490811.

Pickard, S., \& Bessant, J. (Eds.). (2017). Young people re-generating politics times of crises. Palgrave Macmillan. https://doi.org/10. 1007/978-3-319-58250-4.

Popkin, S. L. (1991). The reasoning voter: Communication and persuasion in presidential campaigns. University of Chicago Press.

Prior, M., \& Lupia, A. (2008). Money, time and political knowledge: Distinguishing quick recall from political learning skills. American Journal of Political Science, 52, 168-182.

Putnam, R. (1993). Making democracy work: Civic traditions in modern Italy. Princeton University Press.

Putnam, R. (2000). Bowling alone: The collapse and revival of American community. Simon \& Schuster.
Reichert, F. (2016). How internal political efficacy translates political knowledge into political participation: Evidence from Germany. Europe's Journal of Psychology, 12(2), 221-241. https://doi.org/ 10.5964/ejop.v12i2.1095

Rivat, E., \& Stauer, M. (2012). Political protest. In O. W. Gabriel, S. I. Keil, \& E. Kerrouche (Eds.), Political participation in France and Germany (pp. 237-271). ECPR Press.

Różycka, J. (2012). Życie społeczne jako Gra: kontekst międzykulturowy [Social life as a Game: Intercultural context]. Wydawnictwo Uniwersytetu Gdańskiego.

Schoon, I., \& Cheng, H. (2011). Determinants of political trust: A lifetime learning model. Developmental Psychology, 47(3), 619-631. https://doi.org/10.1037/a0021817

Seagull, L. M. (1971). The youth vote and change in American politics. The Annals of the American Academy of Political and Social Science, 397(1), 88-96. https://doi.org/10.1177/000271627139700 111

The Economist Intelligence Unit. (2020). Democracy index 2019. A year of democratic setbacks and popular protest. https://www.eiu. com/topic/democracy-index. Accessed 08/05/2021

Tolbert, C. J., McNeal, R. S., \& Smith, D. A. (2003). Enhancing civic engagement: The effect of direct democracy on political participation and knowledge. State Politics \& Policy Quarterly, 3(1), 23-41. https://doi.org/10.1177/153244000300300102

van der Meer, T. (2017, January 25). Political trust and the "crisis of democracy". Oxford Research Encyclopedia of Politics. https:// doi.org/10.1093/acrefore/9780190228637.013.77.

van Deth, J. W. (2014). A conceptual map of political participation. Acta Politica, 49(3), 349-367. https://doi.org/10.1057/ap.2014.6

Verba, S., Schlozman, K. L., \& Brady, H. E. (1995). Voice and equality. Civic voluntarism in American politics. Harvard University Press.

Wagner, M., Johann, D., \& Kritzinger, S. (2012). Voting at 16: Turnout and the quality of vote choice. Electoral Studies., 31(2), 372-383. https://doi.org/10.1016/j.electstud.2012.01.007

Wattenberg, M. (2002). Where have all the voters gone? Harvard University Press.

Wuttke, A., Gavras, K., \& Schoen, H. (2020). Have Europeans grown tired of democracy? New evidence from eighteen consolidated democracies, 1981-2018. British Journal of Political Science. Advance online publication. https://doi.org/10.1017/S000712342 0000149 .

Zilinsky, J. (2019). Democratic deconsolidation revisited: Young Europeans are not dissatisfied with democracy. Research \& Politics. Advance online publication. https://doi.org/10.1177/2053168018 814332.

Zmerli, S., \& Newton, K. (2008). Social trust and attitudes toward democracy. Public Opinion Quarterly, 72(4), 706-724. https:// doi.org/10.1093/poq/nfn054

Zmerli, S. (2014). Political trust. In A. C. Michalos (Ed.), Encyclopedia of quality of life and well-being research. Springer. https://doi.org/ 10.1007/978-94-007-0753-5 2202

Publisher's note Springer Nature remains neutral with regard to jurisdictional claims in published maps and institutional affiliations. 